Article

\title{
Effect of Solids-To-Liquids, $\mathrm{Na}_{2} \mathrm{SiO}_{3}-\mathrm{To}-\mathrm{NaOH}$ and Curing Temperature on the Palm Oil Boiler Ash (Si + Ca) Geopolymerisation System
}

\section{Zarina Yahya ${ }^{1, *}$, Mohd Mustafa Al Bakri Abdullah 2,3,*, Kamarudin Hussin 1,2, Khairul Nizar Ismail ${ }^{4}$, Rafiza Abd Razak ${ }^{1}$ and Andrei Victor Sandu 5}

1 Center of Excellence Geopolymer and Green Technology, School of Materials Engineering, Universiti Malaysia Perlis (UniMAP), P.O. Box 77, D/A Pejabat Pos Besar, Kangar 01000, Perlis, Malaysia; E-Mails: vc@unimap.edu.my (K.H.); rafizarazak@unimap.edu.my (R.A.R.)

2 Faculty of Engineering Technology, Uniciti Alam Campus, Universiti Malaysia Perlis, Sungai Chuchuh 02100, Padang Besar, Perlis, Malaysia

3 Faculty of Technology, Universitas Ubudiyah Indonesia, Jl. Alue Naga, Kec. Syiah Kuala Desa Tibang 23536, Banda Aceh, Indonesia

4 School of Environmental Engineering, Universiti Malaysia Perlis (UniMAP), P.O. Box 77, D/A Pejabat Pos Besar, Kangar 01000, Perlis, Malaysia; E-Mail: nizar@unimap.edu.my

5 Faculty of Materials Science and Engineering, Gheorghe Asachi Technical University of Iasi, Blvd. D. Mangeron 41, Iasi 700050, Romania; E-Mail: sav@tuiasi.ro

* Authors to whom correspondence should be addressed; E-Mails: zarinayahya@unimap.edu.my (Z.Y.); mustafa_albakri@unimap.edu.my (M.M.A.B.A.); Tel.: +6-012-5431426 (Z.Y.); +6-012-5055020 (M.M.A.B.A.); Fax: +6-04-9798178 (Z.Y. \& M.M.A.B.A.).

Academic Editor: Jérôme Chevalier

Received: 12 February 2015 / Accepted: 17 April 2015 / Published: 28 April 2015

\begin{abstract}
This paper investigates the effect of the solids-to-liquids (S/L) and $\mathrm{Na}_{2} \mathrm{SiO}_{3} / \mathrm{NaOH}$ ratios on the production of palm oil boiler ash (POBA) based geopolymer. Sodium silicate and sodium hydroxide $(\mathrm{NaOH})$ solution were used as alkaline activator with a $\mathrm{NaOH}$ concentration of $14 \mathrm{M}$. The geopolymer samples were prepared with different $\mathrm{S} / \mathrm{L}$ ratios $(0.5,1.0,1.25,1.5$, and 1.75$)$ and $\mathrm{Na}_{2} \mathrm{SiO}_{3} / \mathrm{NaOH}$ ratios $(0.5,1.0,1.5,2.0,2.5$, and 3.0). The main evaluation techniques in this study were compressive strength, X-Ray Diffraction (XRD), Fourier Transform Infrared Spectroscopy (FTIR), and Scanning Electron Microscope (SEM). The results showed that the maximum compressive strength (11.9 MPa) was obtained at a $\mathrm{S} / \mathrm{L}$ ratio and $\mathrm{Na}_{2} \mathrm{SiO}_{3} / \mathrm{NaOH}$ ratio of 1.5 and 2.5 at seven days of testing.
\end{abstract}


Keywords: POBA; geopolymer; alkaline activator; $\mathrm{NaOH}$; sodium silicate

\section{Introduction}

The study of alkali-activated binder was started by Purdon in the 1940s in which blast furnace slag was activated with sodium hydroxide $(\mathrm{NaOH})$ solution [1]. After that, in the late 1950s and 1960s Glukhovsky invented an alkali activated system which contained calcium silicate hydrate (CSH) and aluminosilicate phases [2]. Besides that, the term geopolymer was introduced by Davidovits in 1972 where it was described as tri-dimensional alumina-silicate which formed at low temperature and short time from naturally occurring alumina-silicates such as kaolin [3]. Geopolymerisation is a geosynthesis where the reaction integrates minerals from alumino-silicate sources $[4,5]$ and an exothermic process is involved. Any raw material rich in silica and alumina or pozzolanic materials which can be dissolved in an alkaline activator solution can hence undergo a geopolymerisation process.

Geopolymer systems can be divided into two types of binding system which are silica-aluminum $(\mathrm{Si}+\mathrm{Al})$ with medium to high alkaline solution and silica-calcium $(\mathrm{Si}+\mathrm{Ca})$ with a mild alkaline solution [6]. For the $(\mathrm{Si}+\mathrm{Al})$ binding system, the source materials included in this system are class $\mathrm{F}$ fly ash and metakaolin due to having silica and alumina content as the main composition. Meanwhile, for the $(\mathrm{Si}+\mathrm{Ca})$ system, ground granulated blast furnace slag (GGBS) was included in this system due to its main composition which is silica and calcium. The hydration products of these two systems are also different where for the $(\mathrm{Si}+\mathrm{Ca})$ system, calcium silicate hydrate $(\mathrm{CSH})$ is the main product and zeolite like polymers are the main products for the $(\mathrm{Si}+\mathrm{Al})$ system.

For the alkaline activator solution, the combination of $\mathrm{NaOH}$ and sodium silicate solution $\left(\mathrm{Na}_{2} \mathrm{SiO}_{3}\right)$ leads to higher geopolymerisation rates compared to hydroxide alone [6]. Moreover, it was proved by $\mathrm{Xu}$ and Van Deventer [7] where different source materials of alumina-silicate mineral are used to produce geopolymer, it required additional silica $(\mathrm{Si})$ for the geopolymerisation process. Alkali hydroxide is required for the dissolution process of aluminosilicate sources, while $\mathrm{Na}_{2} \mathrm{SiO}_{3}$ solution acts as binder [2].

The mix design for geopolymers can be divided into solids/liquid (S/L) and sodium silicate/ $\mathrm{NaOH}$ $\left(\mathrm{Na}_{2} \mathrm{SiO}_{3} / \mathrm{NaOH}\right)$ ratio which is important in developing the mechanical strength of the geopolymer $[6,8]$. Fresh geopolymer paste with a high $\mathrm{S} / \mathrm{L}$ ratio had a low viscosity while geopolymer paste with a low $\mathrm{S} / \mathrm{L}$ ratio resulted in high viscosity [9]. Besides that, geopolymer with a low $\mathrm{S} / \mathrm{L}$ ratio could accelerate the dissolution rate, but it was not applicable to the polycondensation process when high concentrations of $\mathrm{NaOH}$ were used [10]. In addition, the low $\mathrm{S} / \mathrm{L}$ ratio contributed to low strength due to insufficient formation of binder [11].

The influence of the $\mathrm{Na}_{2} \mathrm{SiO}_{3} / \mathrm{NaOH}$ ratio $(0.4,1.5,5.0,10.0$, and 15.0) in natural zeolite based geopolymers showed that increasing the $\mathrm{Na}_{2} \mathrm{SiO}_{3} / \mathrm{NaOH}$ ratio up to 1.5 increased the compressive strength, but beyond that the strength was decreased [12]. This may be due to excessive sodium silicate that retarded the geopolymerisation process by the precipitation of Al-Si phase, which prevented contact between the reacting material and activating solution and decreased the activator content [13]. Researchers have suggested that the optimum $\mathrm{Na}_{2} \mathrm{SiO}_{3} / \mathrm{NaOH}$ ratio to produce high strength geopolymer 
is in the range 0.67-1.00 [14]. Meanwhile, Hardjito et al. [15] investigated the effect of two different $\mathrm{Na}_{2} \mathrm{SiO}_{3} / \mathrm{NaOH}$ ratios $(0.4$ and 2.5$)$ on the performance of fly ash based geopolymer. They found that when the ratio increased the strength of geopolymer also increased.

Malaysia is one of the world's largest producers of palm oil products and as such the waste material from this industry is also widely available and estimated to be about 44.9 million tonnes. The solid wastes are burned in the boiler to generate electricity at the palm oil mill and the palm oil boiler ash (POBA) or bottom ash is obtained at the lower compartment of the boiler. Generally, palm oil fuel ash (POFA) is used as a cement replacement in concrete as POBA contains coarse particles. As such this study investigates the utilization of POBA in geopolymers and the effect of solids-to-liquids ratio (S/L), alkaline activator ratio $\left(\mathrm{Na}_{2} \mathrm{SiO}_{3} / \mathrm{NaOH}\right)$ and curing temperature on geopolymer paste. The results of the geopolymer paste are evaluated in terms of compressive strength, X-Ray Diffraction (XRD), Fourier Transform Infrared Spectroscopy (FTIR), and Scanning Electron Microscope (SEM).

\section{Results and Discussion}

\subsection{Compressive Strength}

The strength of the geopolymer paste with different solid/liquid $(\mathrm{S} / \mathrm{L})$ and $\mathrm{Na}_{2} \mathrm{SiO}_{3} / \mathrm{NaOH}$ ratios is shown in Figure 1. When the $\mathrm{S} / \mathrm{L}$ and $\mathrm{Na}_{2} \mathrm{SiO}_{3} / \mathrm{NaOH}$ ratio increased, the compressive strength also increased. The maximum compressive strength $(11.9 \mathrm{MPa})$ was achieved at $\mathrm{S} / \mathrm{L}$ and $\mathrm{Na}_{2} \mathrm{SiO}_{3} / \mathrm{NaOH}$ ratio of 1.5 and 2.5. Furthermore, at $\mathrm{S} / \mathrm{L}$ ratio 1.0, 1.25 and 1.5 the maximum compressive strength was obtained at a $\mathrm{Na}_{2} \mathrm{SiO}_{3} / \mathrm{NaOH}$ ratio of 2.5. The compressive strength of geopolymer paste increased when the amount of $\mathrm{Na}_{2} \mathrm{SiO}_{3}$ increased. Moreover, the use of $\mathrm{Na}_{2} \mathrm{SiO}_{3}$ helps to improve the geopolymerisation process by accelerating the dissolution of source material [7]. It was observed by Hardjito and Rangan [16] that increasing the $\mathrm{Na}_{2} \mathrm{SiO}_{3} / \mathrm{NaOH}$ ratio increased the geopolymerisation rate. Conversely, when the $\mathrm{Na}_{2} \mathrm{SiO}_{3} / \mathrm{NaOH}$ ratio was more than 3.0 the compressive strength tended to decrease for all $\mathrm{S} / \mathrm{L}$ ratios. This may be due to excessive alkali content which retards the geopolymerisation process. It occurs when $\mathrm{Al}-\mathrm{Si}$ phase precipitation prevents interaction between reacting material and alkaline activator thus reducing the activator concentration [12].

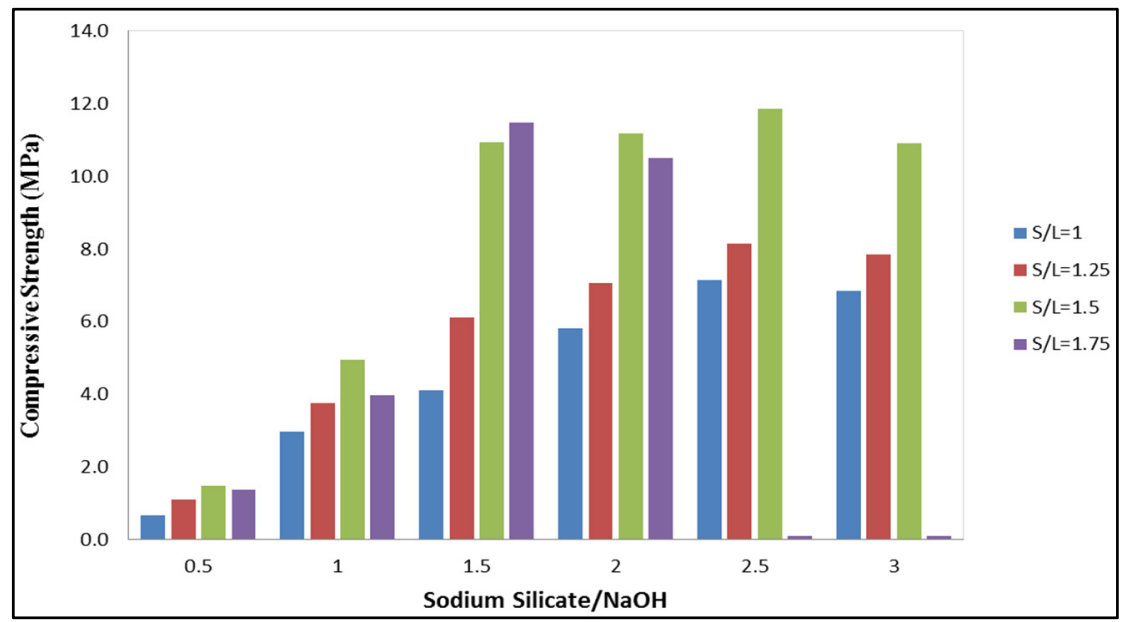

Figure 1. Compressive strength of geopolymer samples with different solid/liquid (S/L) and $\mathrm{Na}_{2} \mathrm{SiO}_{3} / \mathrm{NaOH}$ ratios at 7 days. 
However, at $\mathrm{S} / \mathrm{L}$ ratio 1.75 with $\mathrm{Na}_{2} \mathrm{SiO}_{3} / \mathrm{NaOH}$ ratios 2.5 and 3.0 the geopolymer paste was unable to mix due to lower workability. As such, geopolymer strength was unable to be acquired. This condition showed that the $\mathrm{Na}_{2} \mathrm{SiO}_{3} / \mathrm{NaOH}$ ratio was correlated to the workability and compressive strength of the geopolymer paste. For this $\mathrm{S} / \mathrm{L}$ ratio, the maximum strength $(11.5 \mathrm{MPa})$ was contributed by a geopolymer sample with a $\mathrm{Na}_{2} \mathrm{SiO}_{3} / \mathrm{NaOH}$ ratio 1.5.

Meanwhile, for $\mathrm{S} / \mathrm{L}$ ratio 1.0 and 1.25 contributed a low strength of geopolymer paste and can be due to a high content of alkaline activator. The high content of alkaline activator produced excessive $\mathrm{OH}^{-}$that was left in the system, thus weakening the geopolymer structure [17]. From this study it was shown that $\mathrm{S} / \mathrm{L}$ and $\mathrm{Na}_{2} \mathrm{SiO}_{3} / \mathrm{NaOH}$ ratios did influence the compressive strength and the workability of geopolymers. The optimum mix design for POBA geopolymer paste was obtained at $\mathrm{S} / \mathrm{L}$ and $\mathrm{Na}_{2} \mathrm{SiO}_{3} / \mathrm{NaOH}$ ratios of 1.5 and 2.5 , respectively.

Figure 2 shows the effect of curing temperature on the compressive strength of geopolymer paste where at room temperature (RT) the lowest compressive strength $(0.4 \mathrm{MPa})$ was obtained. Meanwhile, the maximum compressive strength $(11.5 \mathrm{MPa})$ was obtained at a curing temperature $80{ }^{\circ} \mathrm{C}$ for $24 \mathrm{~h}$. When the curing temperature increased, the compressive strength also resulted in an increment. The geopolymer samples displayed increment in strength in the range 3\%-96\% when cured at different temperatures. Hence, from this result it is indicated that geopolymer paste produced using POBA, required heat curing in order to increase the compressive strength. Palomo et al. [6] also mentioned that heat curing acts as an accelerator in the geopolymer production. Heat curing in geopolymers leads to a quicker geopolymerisation process, thus producing adequate strength within a very short period $[16,18-20]$.

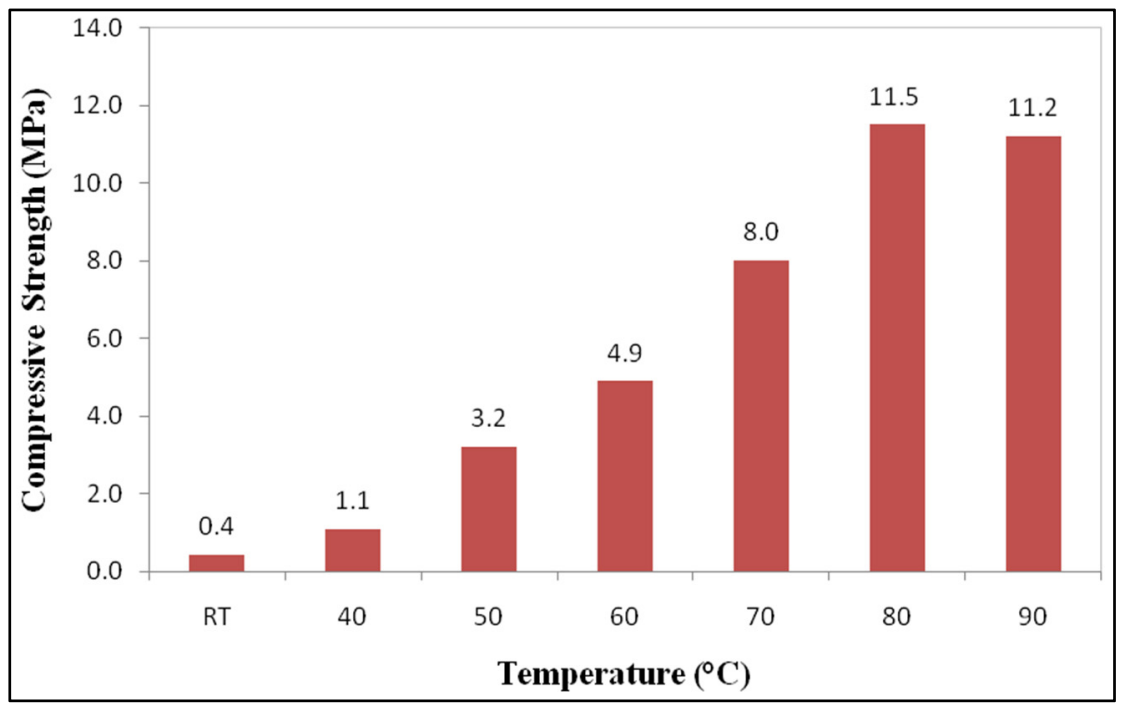

Figure 2. Compressive strength of geopolymer with different curing temperatures at 7 days.

Geopolymer samples exhibited slightly reduced compressive strength after curing at temperature $90{ }^{\circ} \mathrm{C}$. Bakharev [21] found that geopolymer samples cured at $90{ }^{\circ} \mathrm{C}$ experienced a significant loss of moisture. As such, Hardjito et al. [17] concluded that curing samples at higher temperature does not essentially produce higher strength geopolymer products. Moreover, since the geopolymer samples that were produced using a 50mm mould had a high surface-to-volume ratio, this is more vulnerable to heat curing and also loss of moisture, and thus could lead to strength reduction when cured at high temperature [14]. 
Additionally, Chindaprasirt et al. [14] stated that to produce geopolymer with good strength requires the presence of moisture.

\subsection{X-Ray Diffraction (XRD) Analysis}

The X-Ray Diffraction (XRD) analysis for $\mathrm{S} / \mathrm{L}$ of 1.0, 1.25, 1.5, and 1.75 with maximum compressive strength is presented in Figure 3. From the figure it is shown that the highest peak for all mix design was contributed by quartz. At ratio S/L 1.0, only quartz and cristobalite peaks were detected compared to S/L $1.25,1.5$, and 1.75 . However, at ratio $\mathrm{S} / \mathrm{L} 1.25,1.5$ and 1.75 peaks of albite were found at $2 \theta=13^{\circ}$ and $2 \theta=28^{\circ}$, approximately. The highest peak of albite was contributed by S/L 1.5 which is consistent with optimum compressive strength. The peak of albite was attributed to the strength of the geopolymer paste by forming a crystalline phase of the N-A-S-H (aluminosilicate gel) system [22].

The peaks of cristobalite and quartz at $2 \theta=21^{\circ}$ and $2 \theta=22^{\circ}$ in POBA still exists in geopolymer paste. Besides that, the geopolymer paste with the different mix design also demonstrated an amorphous to semi crystalline phase which is the same as with POBA. Since the crystalline peaks were detected more with a $\mathrm{S} / \mathrm{L}$ ratio of 1.5 , it can be concluded that the existence of these peaks helps to increase the strength of the geopolymer paste [23].

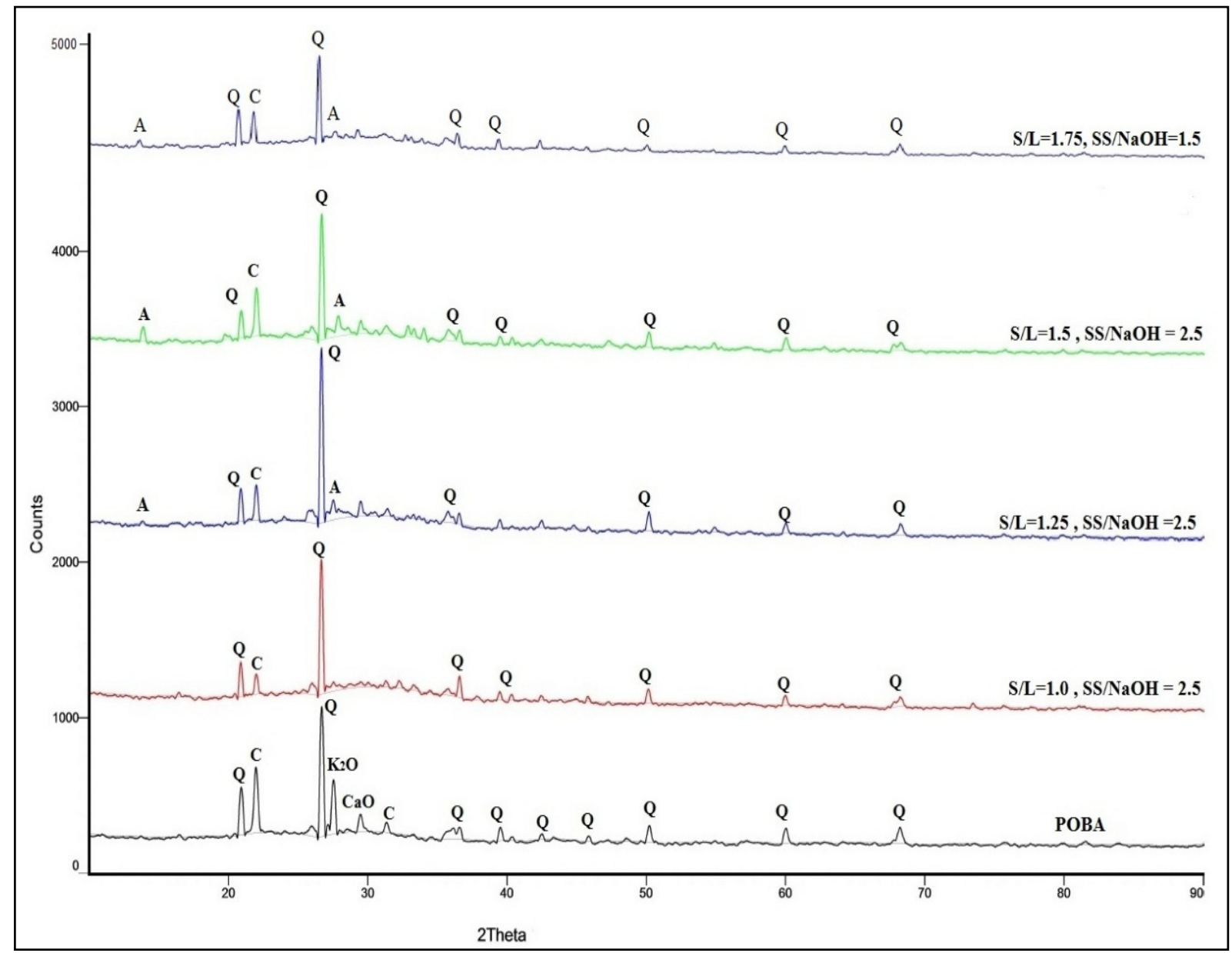

Figure 3. $\mathrm{X}$-Ray Diffraction (XRD) analysis on geopolymer paste with different mix design $\left(\mathrm{Q}=\right.$ quartz, $\mathrm{C}=$ cristobalite, $\mathrm{A}=$ albite, $\mathrm{K}_{2} \mathrm{O}=$ potassium oxide, $\mathrm{CaO}=$ calcium oxide, $\mathrm{C}=$ calcium). 
Figure 4 demonstrates the XRD analysis on geopolymer samples cured with different curing temperatures for $24 \mathrm{~h}$. Quartz and cristobalite were spotted in all samples with maximum peaks of quartz. All the geopolymer samples still displayed the amorphous phase despite being cured at different temperatures. The remaining quartz and cristobalite in geopolymer samples showed that the originally used quantity had not fully reacted during the geopolymerisation process for all temperatures.

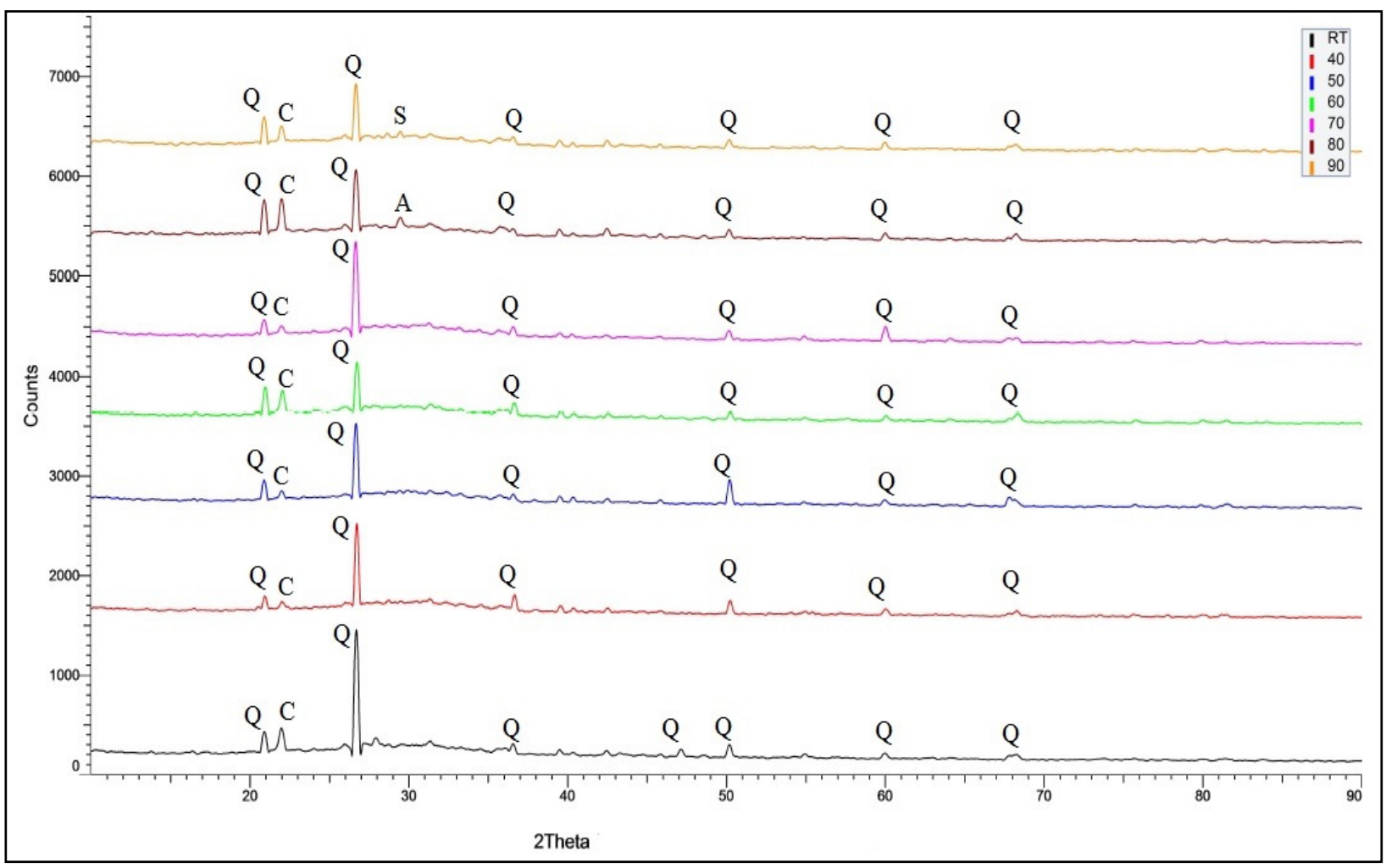

Figure 4. X-Ray Diffraction (XRD) analysis on geopolymer paste with different curing temperatures $(\mathrm{Q}=$ quartz, $\mathrm{C}=$ cristobalite, $\mathrm{A}=$ albite, $\mathrm{S}=$ sodium silicate $)$.

\subsection{Fourier Transform Infrared Spectroscopy (FTIR) Analysis}

Figure 5 displays the IR spectra of geopolymer samples with the different mix design of S/L ratio. The geopolymer samples with optimum strength at each $\mathrm{S} / \mathrm{L}$ ratio were analyzed in this study. The broad bands appearing at $2316-3351 \mathrm{~cm}^{-1}$ were due to stretching vibrations $\mathrm{OH}$ and $\mathrm{HOH}$. In addition, the bending vibration of $\mathrm{HOH}$ was detected at $1651-1655 \mathrm{~cm}^{-1}$. The existence of these bondings was related to entrapped water molecules in the geopolymeric network.

The stretching vibration of O-C-O was still detected in each of the geopolymer samples at 1411-1412 $\mathrm{cm}^{-1}$ [23] which was attributed to the carbonation reaction. The carbonation process occurred because an excessive amount of $\mathrm{Na}$ was available from the alkaline activator solution where it reacted with $\mathrm{CO}_{2}$ from the atmosphere [24].

The band attributed to asymmetric stretching vibration of $\mathrm{Si}-\mathrm{O}-\mathrm{Si}$ and $\mathrm{Al}-\mathrm{O}-\mathrm{Si}$ around area 1011-1027 $\mathrm{cm}^{-1}$ indicated the formation of aluminosilicate gel [25]. Besides that, symmetric stretching vibrations Si-O-Si were located at $778-795 \mathrm{~cm}^{-1}$. At $583-721 \mathrm{~cm}^{-1}$, symmetric stretching vibrations of $\mathrm{Si}-\mathrm{O}-\mathrm{Si}$ and Al-O-Si were identified. In the meantime, the bending vibrations of Si-O-Si and O-Si-O were found at area $467-479 \mathrm{~cm}^{-1}$. 


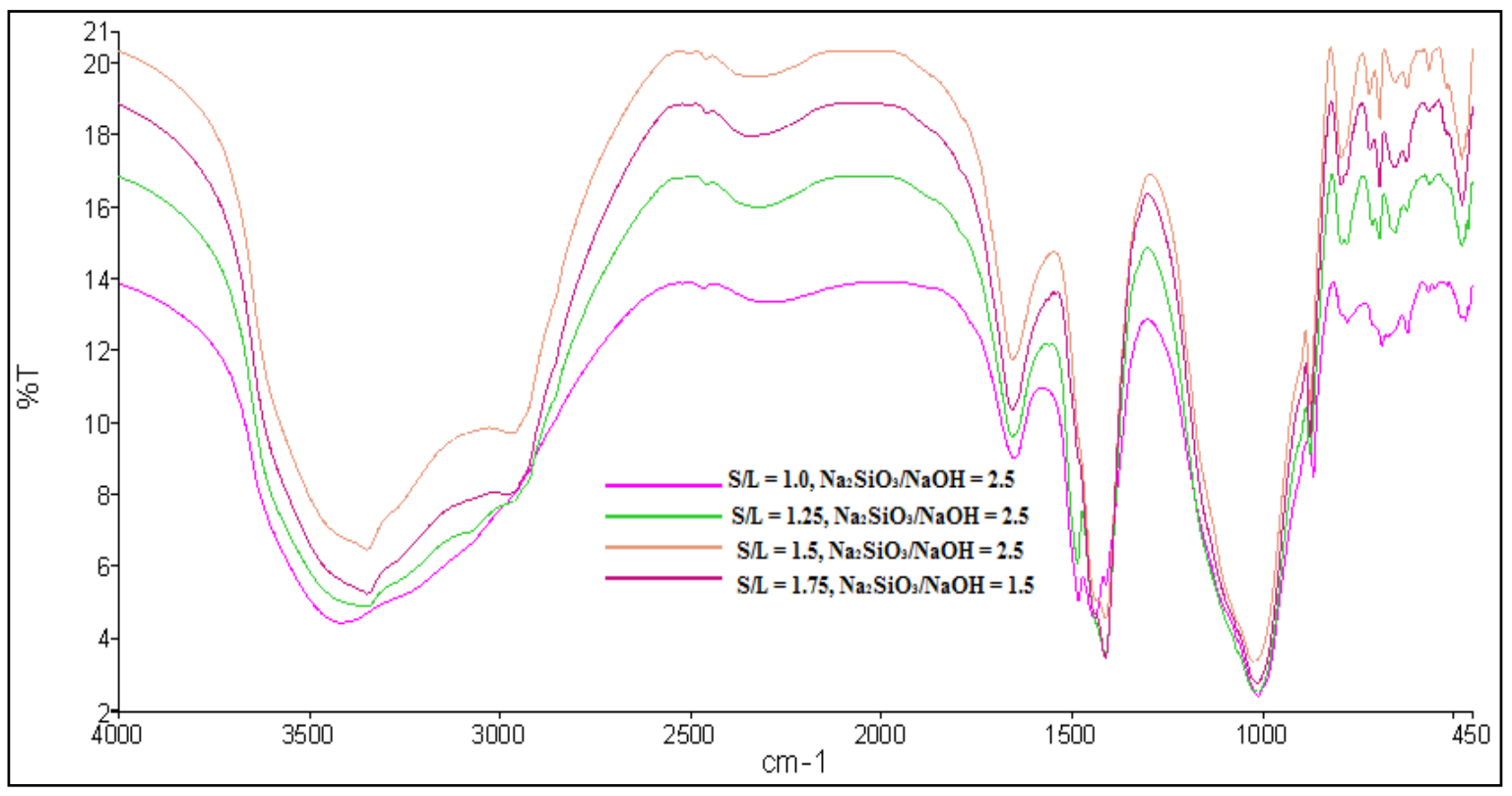

Figure 5. IR spectra of geopolymer paste with different mix design.

The broad band appeared in all IR spectra in the region $2287-3435 \mathrm{~cm}^{-1}$ indicating the presence of stretching vibrations $\mathrm{OH}$ and $\mathrm{HOH}$ as in Figure 6. Meanwhile bending vibration $\mathrm{HOH}$ was detected at $1648-1658 \mathrm{~cm}^{-1}$ where all these bondings represent water molecule. The band at $1412-1432 \mathrm{~cm}^{-1}$ represents the stretching vibration of O-C-O. The aluminosilicate gel (asymmetric stretching vibrations $\mathrm{Si}-\mathrm{O}-\mathrm{Si}$ and $\mathrm{Al}-\mathrm{O}-\mathrm{Si}$ ) were detected at $1011-1023 \mathrm{~cm}^{-1}$. When the curing temperature increased, the asymmetric stretching vibrations Si-O-Si and Al-O-Si also shift to lower frequency. Besides that, the symmetric stretching vibration Si-O-Si was found at $776-794 \mathrm{~cm}^{-1}$.

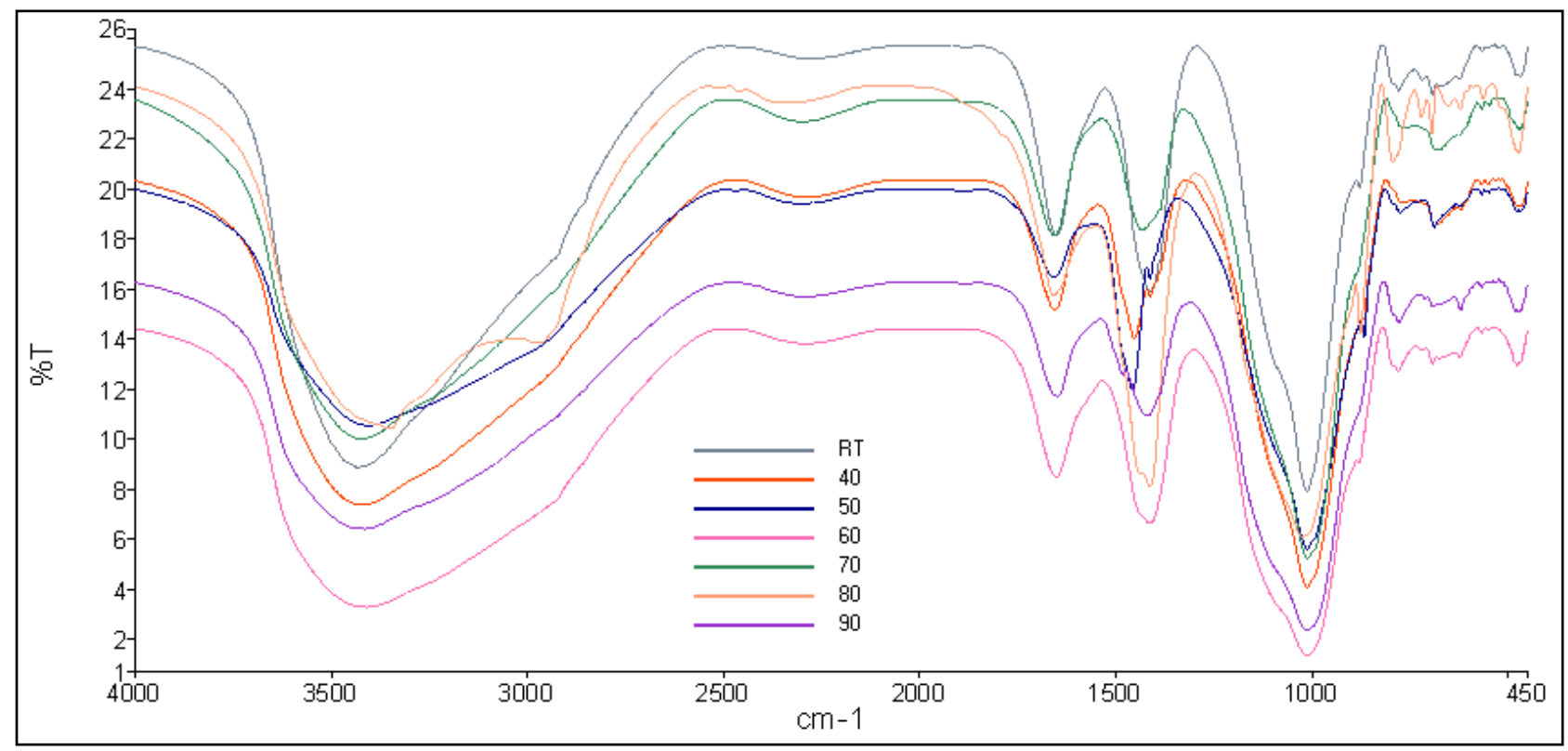

Figure 6. IR spectra of geopolymer paste with different curing temperatures.

In addition, the symmetric stretching vibrations Si-O-Si and Al-O-Si were located at $621-721 \mathrm{~cm}^{-1}$. However, at $467-476 \mathrm{~cm}^{-1}$, bending vibrations $\mathrm{Si}-\mathrm{O}-\mathrm{Si}$ and O-Si-O were identified which represents 
quartz, thus indicating that quartz which originally exists in POBA did not fully react with the alkaline activator solution which correlates with the finding in XRD analysis.

\subsection{Scanning Electron Microscope (SEM) Analysis}

For each $\mathrm{S} / \mathrm{L}$ ratio $(1.0,1.25,1.5$, and 1.75$)$ the samples that contributed the maximum compressive strength are displayed in Figure 7a-d. Geopolymer samples with ratio $\mathrm{S} / \mathrm{L} 1.0$ and $\mathrm{Na}_{2} \mathrm{SiO}_{3} / \mathrm{NaOH} 2.5$ are shown in Figure 7a where it demonstrates incomplete geopolymerisation. This leads to a less dense geopolymer matrix and lower compressive strength (7.2 MPa). Since the quantity of POBA and alkaline activator was equal in this sample, it takes time for the geopolymerisation process to complete.
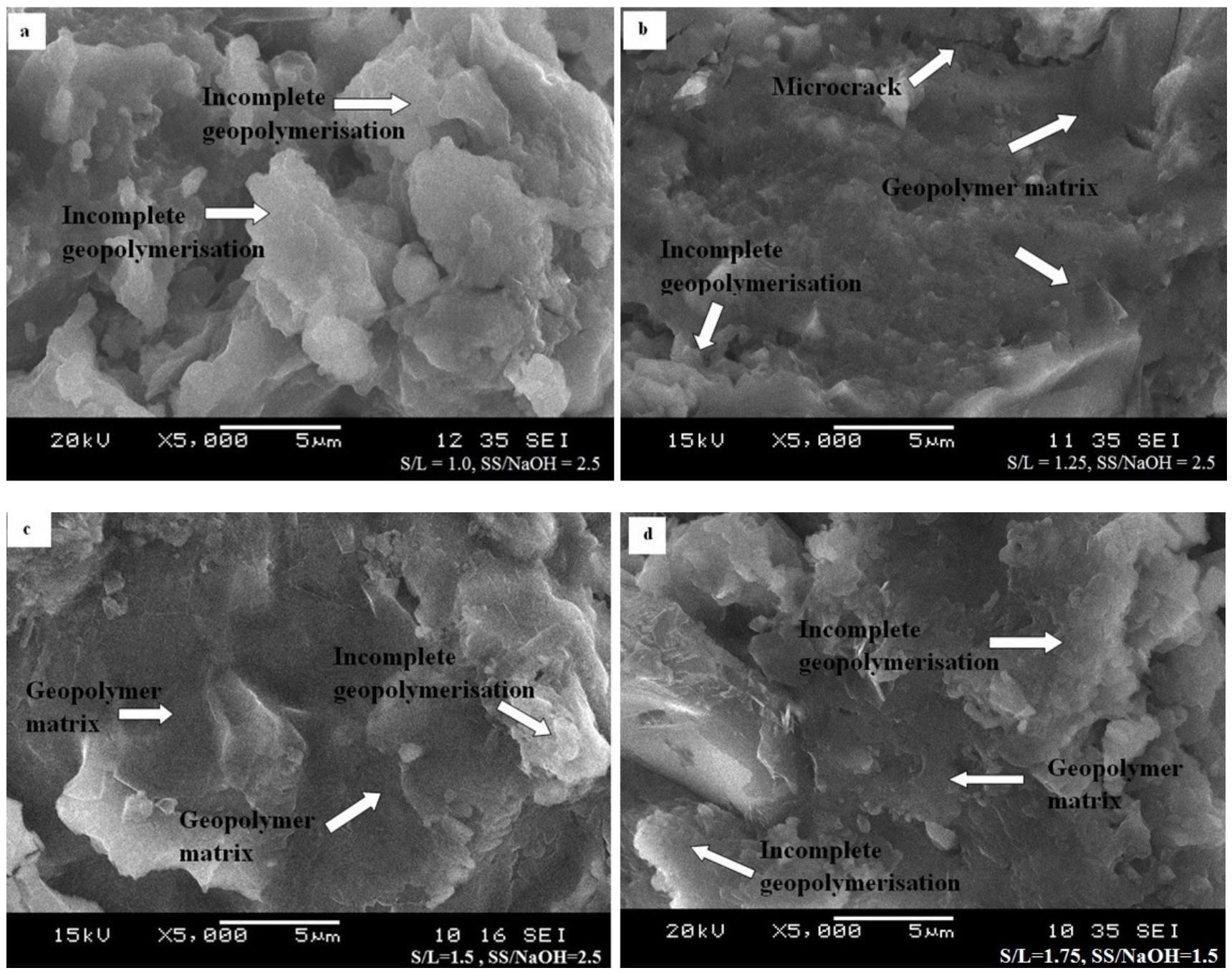

Figure 7. Geopolymer with different mix design. (a) $\mathrm{S} / \mathrm{L}=1.0, \mathrm{Na}_{2} \mathrm{SiO}_{3} / \mathrm{NaOH}=2.5$; (b) $\mathrm{S} / \mathrm{L}=1.25, \mathrm{Na}_{2} \mathrm{SiO}_{3} / \mathrm{NaOH}=2.5$; (c) $\mathrm{S} / \mathrm{L}=1.5, \mathrm{Na}_{2} \mathrm{SiO}_{3} / \mathrm{NaOH}=2.5$; (d) $\mathrm{S} / \mathrm{L}=1.75$, $\mathrm{Na}_{2} \mathrm{SiO}_{3} / \mathrm{NaOH}=1.5$.

Besides that, Figure $7 \mathrm{~b}$ with ratio $\mathrm{S} / \mathrm{L} 1.25$ and $\mathrm{Na}_{2} \mathrm{SiO}_{3} / \mathrm{NaOH} 2.5$ demonstrated a denser geopolymer matrix compared to previous figures. Therefore, the quantity of alkaline activator affects the saturation rate of the geopolymerisation process and the strength of geopolymer. In this sample, microcrack was detected and may be due to the sample preparation for the SEM analysis. 
Geopolymer samples with ratio $\mathrm{S} / \mathrm{L} 1.25$ and $\mathrm{Na}_{2} \mathrm{SiO}_{3} / \mathrm{NaOH} 2.5$ as in Figure $7 \mathrm{c}$ show a denser geopolymer matrix compared to others. It shows POBA reacts homogeneously with alkaline activator thus leading to maximum compressive strength (11.9 MPa). Nevertheless, incomplete geopolymerisation is still observed in this sample.

Figure $7 \mathrm{~d}$ illustrates a geopolymer sample with ratio $\mathrm{S} / \mathrm{L} 1.75$ and $\mathrm{Na}_{2} \mathrm{SiO}_{3} / \mathrm{NaOH} 1.5$ and the maximum compressive strength $(11.5 \mathrm{MPa})$ was obtained. For this mix design with $\mathrm{Na}_{2} \mathrm{SiO}_{3} / \mathrm{NaOH}$ more than 2.0, the geopolymer samples were unable to be prepared due to low workability. As such, from the figure it shows incomplete geopolymerisation due to less alkaline activator available to react with POBA.

The morphology of geopolymer samples with different curing temperature is displayed in Figure 8a-g. Geopolymer cured at room temperature (Figure 8a) displayed more incomplete geopolymerisation compared to other samples. The reaction rate between POBA and alkaline activator occurred very slowly where no solid geopolymer matrix is formed. Subsequently, due to a slow geopolymerisation process, the strength was also low.
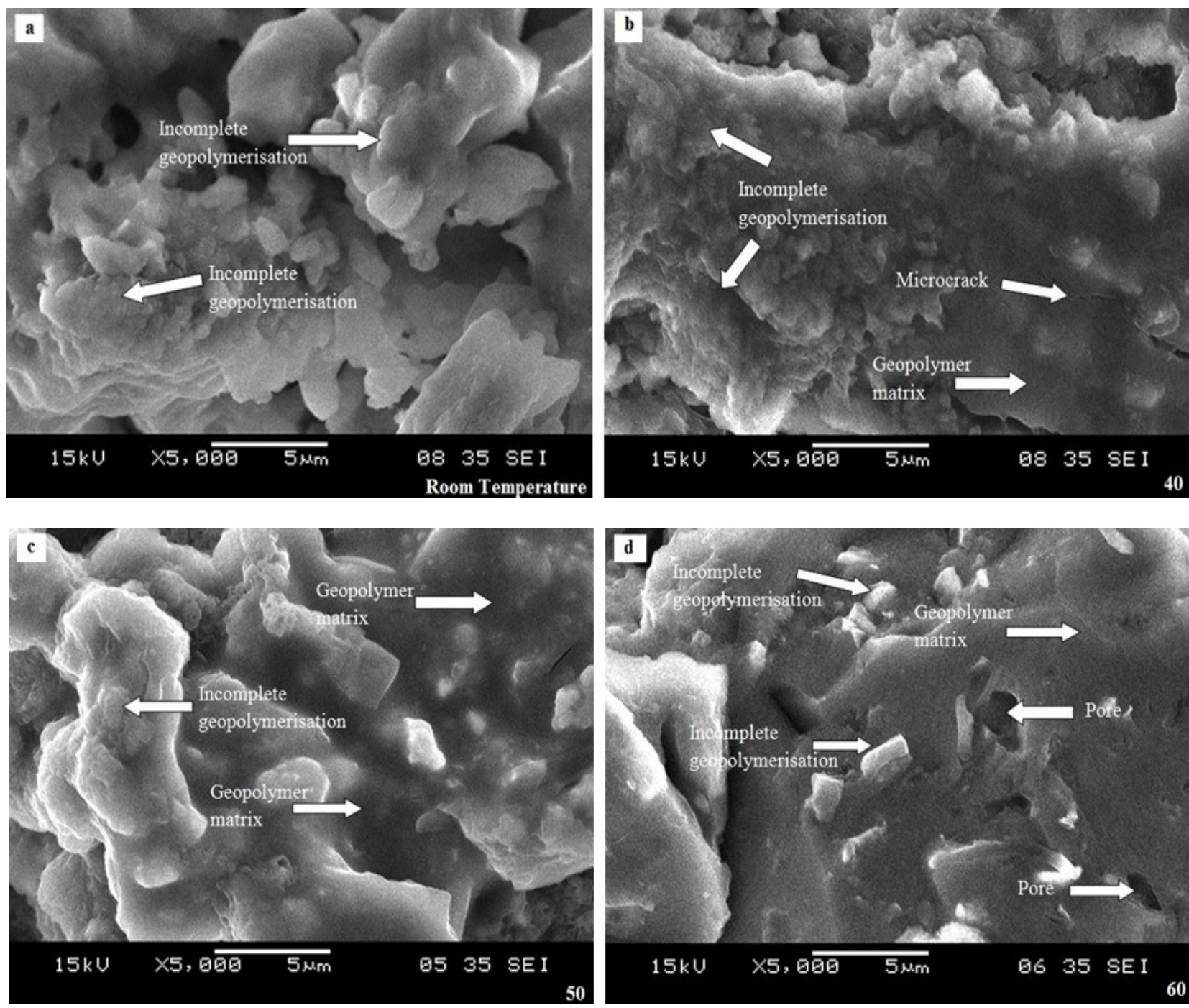

Figure 8. Cont. 

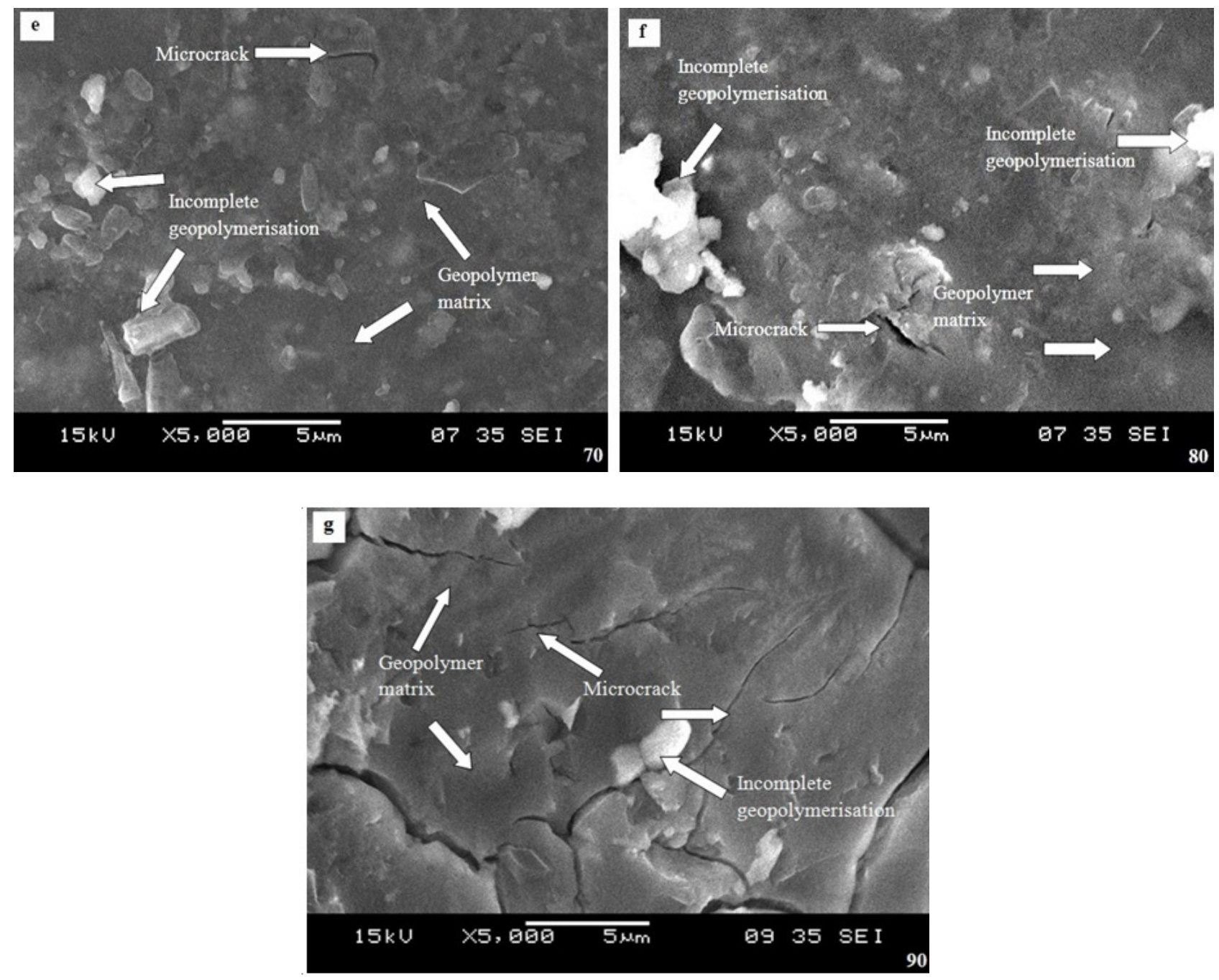

Figure 8. Geopolymer samples with different curing temperatures. (a) Room Temperature; (b) $40{ }^{\circ} \mathrm{C}$; (c) $50{ }^{\circ} \mathrm{C}$; (d) $60{ }^{\circ} \mathrm{C}$; (e) $70{ }^{\circ} \mathrm{C}$; (f) $80{ }^{\circ} \mathrm{C}$; (g) $90{ }^{\circ} \mathrm{C}$.

In the meantime, a geopolymer sample cured at $40{ }^{\circ} \mathrm{C}$ showed less incomplete geopolymerisation and a dense matrix was formed. At this temperature, the geopolymerisation process starts only slowly to form the geopolymer matrix. A dense gel-like matrix imbedded with POBA particles is seen in Figure $8 \mathrm{~b}$. Besides that, the microcrack detected was due to sample preparation for morphological analysis. In Figure 8c, the hardening process in the geopolymerisation covered POBA particles with a dense gel-like matrix. The unreacted POBA particles were seen on the surface of the dense geopolymer matrix. Jaarsveld et al. [26] mentioned that the dissolution of source material is not complete where in many cases the surface reaction is responsible for the formation of the geopolymer final structure in bonding the undissolved particles.

At a curing temperature of $60{ }^{\circ} \mathrm{C}$ (Figure 8d), a dense geopolymer matrix was observed with some unreacted POBA particles. The existence of pores was also detected in this sample. Since a more dense geopolymer structure was produced, the strength also increased. For geopolymer samples cured at $70{ }^{\circ} \mathrm{C}, 80{ }^{\circ} \mathrm{C}$, and $90{ }^{\circ} \mathrm{C}$, dense geopolymer matrix was produced as well as maximum compressive strength at $80^{\circ} \mathrm{C}$. The geopolymerisation process completely occurred when the geopolymer sample was cured at $70{ }^{\circ} \mathrm{C}$. However, many microcracks were observed in the geopolymer sample cured at 
$90{ }^{\circ} \mathrm{C}$. This may be due to the high curing temperature that causes a quick hardening process thus leading to microcracks. The strength also reduces when cured at high temperature.

\section{Experimental Section}

\subsection{Material}

The POBA was obtained from United Palm Oil Mill in Penang, Malaysia where it contained large particles which included unburned nutshells, fibers, and kernels as in Figure 9a. Then the POBA was ground using a heavy duty grinder in order to obtain finer particles. After that, the ground POBA was sieved using $100 \mu \mathrm{m}$ sieves. The POBA that passed through the $100 \mu \mathrm{m}$ sieve (Figure 9b) was used to produce geopolymer paste and the chemical composition is as in Table 1 below [27]. The POBA was classified as a silica-calcium $(\mathrm{Si}+\mathrm{Ca})$ geopolymerisation system due to the high content of silica $(\mathrm{Si})$ and calcium $(\mathrm{Ca})$.

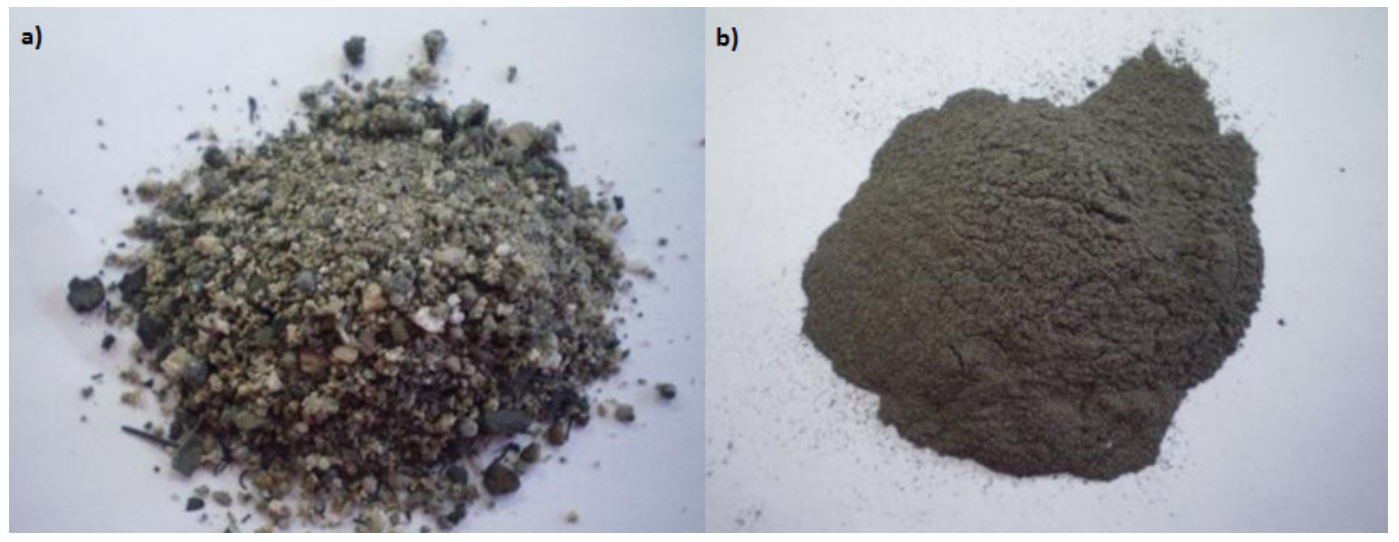

Figure 9. (a) Palm oil boiler ash (POBA); (b) fine POBA.

Table 1. Chemical composition of fine palm oil boiler ash (POBA).

\begin{tabular}{ccc}
\hline No. & Compositions & POBA (wt\%) \\
\hline 1 & $\mathrm{SiO}_{2}$ & 40.60 \\
2 & $\mathrm{Al}_{2} \mathrm{O}_{3}$ & 3.71 \\
3 & $\mathrm{Fe}_{2} \mathrm{O}_{3}$ & 15.74 \\
4 & $\mathrm{CaO}$ & 19.60 \\
5 & $\mathrm{MgO}$ & 1.30 \\
6 & $\mathrm{P}_{2} \mathrm{O}_{5}$ & 2.73 \\
7 & $\mathrm{~K}_{2} \mathrm{O}$ & 13.80 \\
8 & $\mathrm{SO}_{3}$ & 0.44 \\
9 & $\mathrm{TiO}_{2}$ & 0.35 \\
10 & $\mathrm{MnO}$ & 0.28 \\
\hline
\end{tabular}

$\mathrm{NaOH}$ solution and sodium silicate $\left(\mathrm{Na}_{2} \mathrm{SiO}_{3}\right)$ solution were used as alkaline activator to synthesize POBA. NaOH pellets with 99\% purity brand name of Formosoda-P, from the Formosa Plastic Corporation, Taiwan were used to produce the $\mathrm{NaOH}$ solution. The $\mathrm{NaOH}$ solution with $14 \mathrm{M}$ concentration was prepared by diluting $\mathrm{NaOH}$ pellets with distilled water. Sodium silicate $\left(\mathrm{Na}_{2} \mathrm{SiO}_{3}\right)$ solution was obtained from South Pacific Chemical Industries Sdn. Bhd. (SPCI), Malaysia. 


\subsection{Mix Design}

\subsubsection{Solids-to-Liquids $(\mathrm{S} / \mathrm{L})$ and $\mathrm{Na}_{2} \mathrm{SiO}_{3} / \mathrm{NaOH}$}

The fine POBA was mixed with an alkaline activator with four different S/L (POBA/alkaline activator) ratios such as 1.0, 1.25, 1.5, and 1.75. Meanwhile, for alkaline activator solution $\left(\mathrm{Na}_{2} \mathrm{SiO}_{3} / \mathrm{NaOH}\right.$ ratio), six solutions were prepared according to the ratio $0.5,1.0,1.5,2.0,2.5$, and 3.0 [28-31]. Table 2 shows the experimental details for solid/liquid ratios and $\mathrm{Na}_{2} \mathrm{SiO}_{3} / \mathrm{NaOH}$ ratios. All the samples were cured at $80^{\circ} \mathrm{C}$ for $24 \mathrm{~h}$ and left at room temperature for 7 days for compressive strength testing.

\subsubsection{Various Curing Temperatures}

After the optimum $\mathrm{S} / \mathrm{L}$ ratio and $\mathrm{Na}_{2} \mathrm{SiO}_{3} / \mathrm{NaOH}$ was obtained, further study was conducted to investigate the effect of curing temperature. The samples were cured at room temperature $(\mathrm{RT}), 40^{\circ} \mathrm{C}$, $50{ }^{\circ} \mathrm{C}, 60{ }^{\circ} \mathrm{C}, 70^{\circ} \mathrm{C}, 80^{\circ} \mathrm{C}$, and $90^{\circ} \mathrm{C}$ for $24 \mathrm{~h}$ [32]. Then, all the samples were cured at room temperature for 7 days for compressive strength testing.

Table 2. Mix design details for geopolymer pastes.

\begin{tabular}{|c|c|c|c|c|}
\hline S/L Ratio & $\mathrm{Na}_{2} \mathrm{SiO}_{3} / \mathrm{NaOH}$ Ratio & Mass of Solid (g) & $\mathrm{Na}_{2} \mathrm{SiO}_{3}$ Solution $(\mathrm{g})$ & NaOH Solution (g) \\
\hline \multirow{6}{*}{1.0} & 0.5 & \multirow{6}{*}{480} & 160.0 & 320.0 \\
\hline & 1.0 & & 240.0 & 240.0 \\
\hline & 1.5 & & 288.0 & 192.0 \\
\hline & 2.0 & & 320.0 & 160.0 \\
\hline & 2.5 & & 342.9 & 137.1 \\
\hline & 3.0 & & 360.0 & 120.0 \\
\hline \multirow{6}{*}{1.25} & 0.5 & \multirow{6}{*}{480} & 128.0 & 256.0 \\
\hline & 1.0 & & 192.0 & 192.0 \\
\hline & 1.5 & & 230.4 & 153.6 \\
\hline & 2.0 & & 256.0 & 128.0 \\
\hline & 2.5 & & 274.3 & 109.7 \\
\hline & 3.0 & & 288.0 & 96.0 \\
\hline \multirow{6}{*}{1.5} & 0.5 & \multirow{6}{*}{480} & 106.7 & 213.3 \\
\hline & 1.0 & & 160.0 & 160.0 \\
\hline & 1.5 & & 192.0 & 128.0 \\
\hline & 2.0 & & 213.3 & 106.7 \\
\hline & 2.5 & & 228.6 & 91.4 \\
\hline & 3.0 & & 240.0 & 80.0 \\
\hline \multirow{6}{*}{1.75} & 0.5 & \multirow{6}{*}{480} & 91.4 & 182.9 \\
\hline & 1.0 & & 137.1 & 137.1 \\
\hline & 1.5 & & 164.6 & 109.7 \\
\hline & 2.0 & & 182.9 & 91.4 \\
\hline & 2.5 & & 195.9 & 78.4 \\
\hline & 3.0 & & 205.7 & 68.6 \\
\hline
\end{tabular}




\subsection{Mixing Process}

The alkaline activator solution was prepared by mixing $\mathrm{NaOH}$ solution with $\mathrm{Na}_{2} \mathrm{SiO}_{3}$ solution until a homogeneous solution was achieved. Then, the alkaline activator was mixed with POBA in the mechanical mixer for about 5 min approximately. The geopolymer paste was placed in a mould $(50 \times 50 \times 50 \mathrm{~mm})$ and then placed in a vibrating table for $10 \mathrm{~s}$ to remove entrapped air. The geopolymer samples that underwent heat curing were covered with a plastic sheet to avoid moisture loss.

\subsection{Testing}

\subsubsection{Compressive Strength}

The strength of geopolymer pastes was measured using compressive strength testing based on American Society for Testing and Materials (ASTM C109). The testing was carried out using an Instron machine series 5569 Mechanical Tester (Instron, Singapore) with maximum loading $50 \mathrm{KN}$ and speed rate $50 \mathrm{~mm} / \mathrm{min}$. Three samples were used for each mix design to determine the optimum compressive strength.

\subsubsection{X-Ray Diffraction (XRD)}

The phase of geopolymer paste that leads to maximum compressive strength was determined using XRD. The geopolymer paste was crushed into powder and tested using a XRD-6000, Shimadzu X-ray diffractometer using $\mathrm{Cu}-\mathrm{K} \alpha$ radiation generated at $30 \mathrm{Ma}$ and $40 \mathrm{kV}$. The samples were tested in powder form starting from $10^{\circ}$ to $90^{\circ}(2 \theta)$ at $0.04^{\circ}$ steps with step time $1.0 \mathrm{~s}$.

\subsubsection{Fourier Transform Infrared Spectroscopy (FTIR)}

The FTIR analysis was conducted using a Perkin Elmer FTIR Spectrum RX1 Spectrometer. The samples of geopolymer paste were prepared in powder form where they were mixed with potassium bromide (KBr), then a cold press machine was used with a 4 ton loading for $2 \mathrm{~min}$. All the samples used wavelengths from $450 \mathrm{~cm}^{-1}$ to $4000 \mathrm{~cm}^{-1}$.

\subsubsection{Microstructure Analysis}

The microstructure of POBA geopolymer paste was observed using Scanning Electron Microscope (SEM). The geopolymer paste samples were cut into small pieces and coated with platinum by using an Auto Fine Coater. A JSM-6460LA model Scanning Electron Microscope (JEOL, Pleasanton, CA, USA) was used in this analysis.

\section{Conclusions}

From this study the results led to the conclusions below:

(a) The optimum mix design for geopolymer paste using POBA is $\mathrm{S} / \mathrm{L}=1.5$ and $\mathrm{Na}_{2} \mathrm{SiO}_{3} / \mathrm{NaOH}=2.5$ with maximum compressive strength $11.9 \mathrm{MPa}$. During XRD analysis, the existence of albite which is due to the formation of an aluminosilicate gel was detected in the 
optimum mix design. The ratio of $\mathrm{Na}_{2} \mathrm{SiO}_{3} / \mathrm{NaOH}$ also plays an important role in the mix design of the geopolymer paste. When the ratio of $\mathrm{Na}_{2} \mathrm{SiO}_{3} / \mathrm{NaOH}$ is more than 2.5 , the compressive strength for $\mathrm{S} / \mathrm{L}(1.0,1.25$, and 1.5) tends to decrease due to excessive alkali content that retards the geopolymerisation process.

(b) The optimum curing temperature for POBA in this study was $80{ }^{\circ} \mathrm{C}$ which led to maximum compressive strength $(11.5 \mathrm{MPa})$ at $24 \mathrm{~h}$ curing period. Thus, heat curing for geopolymer is needed in order to obtain sufficient strength and with heat curing, the geopolymerisation becomes more rapid. The presence of albite during XRD analysis was also detected in the geopolymer sample cured at $80^{\circ} \mathrm{C}$. The morphology of the geopolymer samples showed changes in the matrix when the curing temperature was increased.

\section{Acknowledgments}

We would like to extend our appreciation to the United Palm Oil, Center of Excellence Geopolymer and Green Technology in the School of Materials Engineering at the Universiti Malaysia Perlis (UniMAP).

\section{Author Contributions}

ZarinaYahya designed the overallanalysis and interpretation of data. Mohd Mustafa Al Bakri Abdullah responsible for research publication. Kamarudin Hussin and Khairul Nizar Ismail contributed to the design of the study. Rafiza Abd Razak involves in the production of samples. Andrei Victor Sandu involves in X-Ray Diffraction (XRD) analysis.

\section{Conflicts of Interest}

The authors declare no conflict of interest.

\section{References}

1. Pacheco-Torgal, F.; Castro-Gomes, J.; Jalali, S. Alkali-activated binders: A review. Part 1. Historical background, terminology, reaction mechanism and hydration products. Constr. Build. Mater. 2008, 22, 1305-1314.

2. Komnitsas, K.; Zaharaki, D. Geopolymerisation: A review and prospect for the mineral industry. Miner. Eng. 2007, 20, 1261-1277.

3. Davidovits, J. Soft mineralurgy and geopolymer. In Proceedings of the 1st International Conference on Geopolymer '88, Compiegne, France, 1-3 June 1988; Davidovits, J., Orlinski, J., Eds.; Volume 1, pp. 19-23.

4. Hermann, E.; Kunze, C.; Gatzweiler, R.; Davidovits, J. Solidification of various radioactive residues by geopolymer with special emphasis on long term stability. In Proceedings of the Geopolymers Conference, Saint-Quentin, France, 30 June 1999.

5. Rafiza, A.R.; Mustafa Al Bakri, M.A.; Kamarudin, H.; Khairul Nizar, I.; Ioan, G.S.; Hardjito, D.; Zarina, Y.; Andrei, V.S. Assessment on the potential of volcano ash as artificial lightweight aggregates using geopolymerisation method. Revista de Chimie 2014, 65, 828-834. 
6. Palomo, A.; Grutzeck, M.W.; Blanco, M.T. Alkali-activated fly ashes, a cement for the future. Cement Concrete Res. 1999, 29, 1323-1329.

7. Xu, H.; van Deventer J.S.J. The geopolymerisation of alumino-silicate minerals. Int. J. Miner. Process. 2000, 59, 247-266.

8. Van jaarsveld, J.G.S.; van Deventer, J.S.J.; Lukey, G.C. The effect of composition and temperature on the properties of fly ash and kaolinite-based geopolymers. Chem. Eng. J. 2002, 89, 63-73.

9. Yao, X.; Zhang, Z.; Zhu, H.; Chen, Y. Geopolymerization Process of alkali-metakaolinite characterized by isothermal calorimetry. Thermochim. Acta 2009, 493, 49-54.

10. Zuhua, Z.; Xiao, Y.; Yue, C. Role of water in the synthesis of calcined kaolin-based geopolymer. Appl. Clay Sci. 2009, 43, 218-223.

11. Provis, J.L.; Yong, C.Z.; Duxson, P.; van Deventer, J.S.J. Correlating mechanical and thermal properties of sodium silicate-fly ash geopolymers. Colloids Surf. A: Physicochem. Eng. Asp. 2009, 336, 57-63.

12. Villa, C.; Pecina, E.T.; Torres, R.; Gomez, L. Geopolymer synthesis using alkaline activation of natural zeolite. Constr. Build. Mater. 2010, 24, 2084-2090.

13. Lee, W.K.W.; van Deventer, J.S.J. The effects of inorganic salt contamination on the strength and durability of geopolymers. Colloids Surf. A: Physicochem. Eng. Asp. 2002, 211, 115-126.

14. Chindaprasirt, P.; Chareerat, T.; Sirivivatnanon, V. Workability and strength of coarse high calcium fly ash geopolymer. Cement Concrete Compos. 2007, 29, 224-229.

15. Hardjito, D.; Wallah, S.E.; Sumajouw, D.M.J.; Rangan, B.V. Development fly ash-based geopolymer concrete. ACI Mater. J. 2004, 101, 467-472.

16. Hardjito, D.; Wallah, S.E.; Sumajouw, D.M.J.; Rangan, B.V. Fly ash-based geopolymer concrete. Austr. J. Struct. Eng. 2005, 6, 1-9.

17. Hardjito, D.; Cheak, C.C.; Ing, C.H.L. Strength and setting times of low calcium fly ash-based geopolymer mortar. Mod. Appl. Sci. 2008, 2, 3-11.

18. Hardjito, D.; Rangan, B.V. Development and properties of low-calcium fly ash based geopolymer concrete. In Research Report GC1; Faculty of Engineering, Curtin University of Technology: Perth, Australia, 2005.

19. Matthew, R.; Brian, O.C. Chemical optimisation of the compressive strength of luminosilicate geopolymers synthesised by sodium silicate activation of metakaolinite. J. Mater. Chem. 2003, 13, 1161-1165.

20. Wan Mastura, W.I.; Mustafa Al Bakri, A.M.; Andrei, V.S.; Kamarudin, H.; Ioan G.S.; Khairul Nizar, I.; Aeslina, A.K.; Binhussain, M. Processing and characterization of fly ash-based geopolymer bricks. Revista de Chimie 2014, 65, 1340-1345.

21. Bakharev, T. Geopolymeric materials prepared using class F fly ash and elevated temperature curing. Cement Concrete Res. 2005, 25, 1224-1232.

22. Garcia-Lodeiro, I.; Fernandez-Jimenez, A.; Palomo, A.; Macphee, D.E. Effect of Fresh C-S-H gels of the simultaneous addition of alkali and aluminium. Cement Concrete Res. 2010, 40, 27-32.

23. Alvarez-Ayuso, E.; Querol, X.; Plana, F.; Alastuey, A.; Moreno, N.; Izquierdo, M.; Font, O.; Moreno, T.; Diez, S.; Vázquez, E.; Barra, M. Environmental, physical and structural characterisation of geopolymer matrixes synthesised from coal (co-) combustion fly ashes. J. Hazard. Mater. 2008, 154, 175-183. 
24. Panias, D.; Giannopoulou, I.P.; Perraki, T. Effect of synthesis parameters on the mechanical properties of fly ash-based geopolymers. Colloids Surf. A 2007, 301, 246-254.

25. Nath, S.K.; Kumar, S. Influence of iron making slags on strength and microstructure of fly ash geopolymer. Constr. Build. Mater. 2013, 38, 924-930.

26. Jaarsveld, J.G.S.; Deventer, J.S.J.; Lukey, G.C. The characterization of source materials in fly ash-based geopolymers. Mater. Lett. 2003, 57, 1272-1280.

27. Zarina, Y.; Mustafa Al Bakri, A.M.; Kamarudin, H.; Khairul Nizar, I.; Andrei, V.S.; Petrica, V.; Rafiza, A.R. Chemical and physical characterization of boiler ash from palm oil industry waste for geopolymer composite. Revista de Chimie 2013, 64, 1408-1412.

28. Chub-uppakarn, T.; Thaenlek, N.; Thaisiam, R. Palm ash-based geopolymer mortar incorporating metakaolin. In Proceedings of the Pure and Applied Chemistry International Conference, Bangkok, Thailand, 5-7 January 2011; pp. 347-350.

29. Ariffin, M.A.M.; Hussin, M.; Warid, M.; Rafique Bhutta, M.A. Mix design and compressive strength of geopolymer concrete containing blended ash from agro-industrial wastes. Adv. Mater. Res. 2011, 339, 452-457.

30. Abdullah, M.M.A.; Kamarudin, H.; Mohammed, H.; Khairul Nizar, I.; Rafiza, A.R.; Zarina, Y. The relationship of $\mathrm{NaOH}$ molarity, $\mathrm{Na}_{2} \mathrm{SiO}_{3} / \mathrm{NaOH}$ ratio, fly ash/alkaline activator ratio and curing temperature to the strength of fly ash-based geopolymer. Adv. Mater. Res. 2011, 328-330, $1475-1482$.

31. Mustafa Al Bakri, A.M.; Kamarudin, H.; Binhussain, M.; Rafiza, A.R.; Zarina, Y. Effect of $\mathrm{Na}_{2} \mathrm{SiO}_{3} / \mathrm{NaOH}$ ratios and $\mathrm{NaOH}$ molarities on compressive strength of fly-ash-based geopolymer. ACI Mater. J. 2012, 109, 503-508.

32. Mustafa Al Bakri, A.M.; Kamarudin, H.; BinHussain, M.; Khairul Nizar, I.; Zarina, Y.; Rafiza, A.R. The effect of curing temperature on physical and chemical properties of geopolymers. Phys. Procedia 2011, 22, 286-291.

(C) 2015 by the authors; licensee MDPI, Basel, Switzerland. This article is an open access article distributed under the terms and conditions of the Creative Commons Attribution license (http://creativecommons.org/licenses/by/4.0/). 